\title{
Manajemen Konflik dalam Pengembangan Wisata Desa Cibitung Wetan, Kecamatan Pamijahan, Kabupaten Bogor
}

\section{Conflict Management in Developing Tourism in Cibitung Wetan Village, Pamijahan District, Bogor Regency}

\author{
Nia Kurniati ${ }^{1, *}$, Djuara Lubis, Rilus A. Kinseng \\ ${ }^{1}$ Program Studi Magister Pengembangan Masyarakat, Sekolah Pascasarjana IPB University, Bogor 16680, Indonesia \\ ${ }^{*}$ E-mail korespondensi: nia.k1404@gmail.com
}

Received: August 5, 2021 | Revised: December 15, 2021 | Accepted: December 29, 2021| Online publication: January 11, 2022

\section{ABSTRACT}

As a community develops, conflicts are inevitable. This case also applies to the Curug Cikuluwung tourism community. This research aims to analyze the conflicts, and how to manage the conflicts. This study used a qualitative approach with a case study method. The results of the study indicate that there are two conflicts that have occurred in the tourism development of Curug Cikuluwung village, namely, the first is a conflict between BUMDes and residents from a neighboring village (Pamijahan Village), the second is a conflict between the core manager of Curug Cikuluwung village tourism and the Cibitung Wetan village government. The first conflict has already had a solution, but the second conflict has no solution yet. The community has practiced community-based conflict management but it has not yet become a solution. Therefore, there is a need for mediation from parties who have authority over village tourism to mediate the conflict parties from the Pamijahan District Government, the Bogor Tourism Office, Bogor Village Community Empowerment office, and or Indonesia Power Company.

Keywords: analysis of conflict, analysis of stakeholders, community-based tourism, conflict management

\section{ABSTRAK}

Seiring dengan berkembangnya sebuah komunitas, konflik pun pasti terjadi. Hal ini pun berlaku untuk komunitas wisata Curug Cikuluwung. Penelitian ini bertujuan menganalisis konflik dan bagaimana pengelolaannya. Penelitian ini menggunakan pendekatan kualitatif dengan metode studi kasus. Hasil penelitian ini menunjukkan terdapat dua peristiwa konflik pada pengembangan wisata Desa Cibitung Wetan, yakni konflik antara BUMDes dengan warga dari desa tetangga (Desa Pamijahan) dan konflik antara pengelola inti wisata desa Curug Cikuluwung dengan pemerintah Desa Cibitung Wetan. Konflik pertama sudah ada solusinya, namun konflik kedua belum ada solusinya. Upaya-upaya untuk menyelesaikan konflik sudah dilakukan oleh komunitas berupa manajemen konflik berbasis komunitas (Community-Based Conflict Management), namun belum menjadi solusi. Perlu ada mediasi dari pihak-pihak yang memiliki kewenangan atas wisata desa untuk memfasilitasi atau memediasi pihakpihak yang berkonflik seperti dari Pemerintahan Kecamatan Pamijahan, Dinas Pariwisata Kabupaten Bogor, Dinas Pemberdayaan Masyarakat Desa Kabupaten Bogor dan atau dari PT Indonesia Power.

Kata kunci: analisis konflik, analisis stakeholders, pariwisata berbasis komunitas, manajemen konflik 


\section{PENDAHULUAN}

Pariwisata merupakan sektor yang strategis dan menjadi media integrasi program antar sektor pembangunan. Oleh karena itu, pariwisata sangat masuk akal ditetapkan menjadi leading sector pembangunan karena dapat menggerakkan perekonomian bangsa (Pariwisata, 2018). Pariwisata Indonesia menjadi salah satu sektor yang diprioritaskan oleh pemerintah, dan menjadi salah satu penyumbang devisa negara (Pariwisata, 2018; Rahman et al., 2020; Susyanti \& Latianingsih, 2014; Sutiarani \& Rahmafitria, 2016). Di Indonesia, antara pertumbuhan ekonomi dan pariwisata memiliki hubungan kausalitas timbal balik, yakni pertumbuhan pariwisata dan pertumbuhan ekonomi saling memberikan manfaat satu dengan yang lain (Nizar, 2015).

Pertumbuhan pariwisata yang fenomenal merupakan salah satu penggerak sosio-ekonomi di seluruh dunia. Selain itu, pariwisata juga memberi dampak pada pembangunan dunia, kemakmuran dan kesejahteraan. Oleh karena itu, penyelenggaraan pariwisata perlu dijaga keberlangsungannya. Pariwisata berkelanjutan merupakan pariwisata yang menghormati penduduk setempat dan wisatawan lain, warisan budaya dan lingkungan. Terdapat 3 (tiga) pilar yang harus diseimbangkan agar pembangunan pariwisata berkelanjutan dapat berlangsung dalam jangka panjang yaitu pilar sosial (community), pilar lingkungan (environment) dan pilar ekonomi (economy) (Pariwisata, 2018).

Desa wisata berkontribusi dalam pembangunan berkelanjutan dari level akar rumput, dengan mengikutsertakan penduduk lokal pada mata rantai wisata dan pembinaan pendidikan, keterampilan dan pengelolaan lokal. Kearifan lokal sebagai dasar pembangunan berkelanjutan dalam pariwisata pedesaan yang dapat disimpulkan dari penelitian ini adalah partisipasi masyarakat (Falak et al., 2014; Purbasari \& Manaf, 2017; Purmada et al., 2016; Rizkianto \& Topowijono, 2018; Vitasurya, 2016). Wisata pedesaan dianggap sebagai daya tarik dalam destinasi yang secara signifikan merangsang pertumbuhan ekonomi, khususnya untuk komunitas lokal (Ahsani et al., 2018; Situmorang et al., 2019; Yachya et al., 2016). Pengembangan pariwisata daerah pedesaan adalah dampak dari perubahan minat wisatawan ke daerah turis tujuan. Tren yang berkembang dan motivasi perjalanan wisata khusus untuk kembali ke alam untuk berinteraksi dengan komunitas lokal dan minat untuk mempelajari keunikan budaya lokal mendorong pengembangan pariwisata di daerah pedesaan (Asmaniati et al., 2017).

Community-Based Tourism dapat membantu masyarakat lokal dalam menghasilkan pendapatan, mendiversifikasi ekonomi lokal, melestarikan budaya, melestarikan lingkungan dan menyediakan peluang pendidikan. CBT dipahami untuk dikelola dan dimiliki oleh masyarakat dan untuk masyarakat (Purbasari \& Manaf, 2017). Jenis pariwisata ini akan melibatkan partisipasi masyarakat baik sebagai pelaku langsung maupun sebagai pendukung pariwisata (Rahayu et al., 2016).

Community-Based Tourism merupakan salah satu bentuk dari pariwisata berkelanjutan. Pengelolaan pariwisata berkelanjutan ini tidaklah mudah. Konflik seringkali terjadi di antara para pengelolanya. Konflik umumnya melibatkan para stakeholder seperti misalnya antara masyarakat lokal dan pemerintah. Politik perseteruan (contentious politics) di sektor pariwisata ini tidak hanya dipahami sebagai masalah tunggal, tetapi konflik tersebut merupakan pertautan kompleksitas masalah dari berbagai aktor, sektor, mekanisme dan proses (Afala, 2017; Sari et al., 2017). Adanya perbedaan kepentingan antara masyarakat dan pengelola, memicu konflik yang mengakibatkan kesenjangan sosial (Fitriyana, 2016; Garsetiasih \& Alikodra, 2015; Hanifah, 2018). Sejalan dengan itu, Kinseng et al. (2018) menyatakan bahwa pengembangan pariwisata selain dapat berdampak positif, juga dapat berdampak negatif. Dampak positif di antaranya yaitu meningkatkan akses perekonomian, pendidikan, kesehatan. Sementara, dampak negatifnya adalah konflik sosial antara masyarakat setempat dengan perusahaan (Kinseng et al., 2018). 
Manajemen konflik berbasis komunitas, umumnya perlu memperhatikan prinsip-prinsip pengembangan masyarakat, di antaranya 1) holisme, 2) berkelanjutan, 3) keanekaragaman, 4) perkembangan organik, 5) perkembangan yang seimbang, 6) mengatasi struktur yang merugikan, 7) pemberdayaan, 8) menghargai pengetahuan lokal, 9) menghargai budaya lokal, 10) menghargai sumber daya lokal, 11) menghargai keterampilan masyarakat lokal, 12) menghargai proses lokal, 13) partisipasi, 14) proses, hasil, dan visi, 15) integritas proses, 16) menumbuhkan kesadaran, 17) kerjasama dan konsensus, 18) langkah pembangunan (pengembangan masyarakat merupakan proses jangka panjang), 19) perdamaian dan anti kekerasan, 20) inklusivitas atau merangkul, tidak memprovokasi, merespons provokasi dengan cara-cara tanpa kekerasan, 21) membangun masyarakat (Ife \& Tesoriero, 2016).

Engel dan Korf (2005) menjelaskan ragam pengelolaan konflik berupa kontinum mulai dari avoidance/menghindar (tindakan yang mencegah atau menghindar terjadinya konflik), negotiation/negosiasi (proses tawar-menawar yang dilakukan secara sukarela oleh pihak yang berkonflik), mediation/mediasi (menggunakan pihak ketiga untuk proses mediasi), arbitration/arbitrasi (menyerahkan penyelesaian konflik kepada pihak ketiga yang akan membuat keputusan bagi pihak yang berkonflik) dan adjudication/ajudikasi (bersandar pada keputusan hakim). Sejalan dengan prinsip-prinsip pengembangan masyarakat dari Jim Ife, pengelolaan konflik berbasis komunitas menurut Angel dan Korf maksimal sampai pada tahap mediasi, karena tiga tahap pertama merupakan pengelolaan konflik menang-menang (win-win solution), sedangkan dua tahap terakhir merupakan pengelolaan konflik yang lebih bersifat menang-kalah (win-lose solution) (Engel \& Korf, 2005).

Curug Cikuluwung yang terdapat di Desa Cibitung Wetan, Kecamatan Pamijahan, Kabupaten Bogor merupakan wisata desa yang berkonsep CBT (Community-Based Tourism). Berkembangnya wisata desa Curug Cikuluwung di Desa Cibitung Wetan, Pamijahan Bogor telah memberikan dampak positif dan negatif bagi kehidupan sosial-budaya dan perekonomian masyarakat Desa Cibitung Wetan. Dalam pengelolaannya, wisata desa Curug Cikuluwung melibatkan stakeholder yang terdiri dari komunitas wisata Curug Cikuluwung dan pemerintahan desa atau dalam hal ini adalah BUMDes. Dalam pengelolaan desa wisata ini, konflikpun pasti tidak bisa dihindarkan. Sekalipun konflik dapat berfungsi positif (Coser, 1964), namun konflik yang keras dan memusnahkan harus diatasi (Fisher et al., 2001) karena dapat menghambat proses pembangunan pariwisata. Pengelolaan konflik dapat dilakukan secara tepat bila didasarkan pada pemahaman terhadap potensi konflik ataupun konflik yang sedang terjadi. Penelitian ini ditujukan untuk menganalisis bagaimana konflik yang terjadi dalam pengembangan wisata desa Curug Cikuluwung yang meliputi, urutan kejadian konflik, isu-isu konflik, aktor yang terlibat dalam konflik, tahapan konflik, dan akibat konflik serta merumuskan strategi manajemen konflik di komunitas wisata desa Curug Cikuluwung yang diharapkan bisa berkontribusi dalam pengembangan wisata desa Curug Cikuluwung pada khususnya, umumnya untuk pengembangan wisata desa di Desa Cibitung Wetan.

\section{METODE}

Penelitian ini menggunakan pendekatan kualitatif dengan metode studi kasus, penelitian kualitatif didefinisikan sebagai sebuah proses penyelidikan untuk memahami masalah sosial atau masalah manusia, untuk memperoleh gambaran holistic yang dibentuk dengan kata-kata, melaporkan pandangan informan secara terperinci, dan disusun dalam sebuah latar alamiah (Creswell, 2002). Studi kasus adalah uraian dan penjelasan komprehensif mengenai berbagai aspek seorang individu, suatu kelompok, suatu organisasi (komunitas), suatu program, atau suatu situasi social (Mulyana, 2004). Dalam pendekatan kualitatif peneliti berusaha untuk "mengerti" suatu realitas atau fakta sosial dalam pengembangan masyarakat.

Penelitian ini dilaksanakan di Desa Cibitung Wetan, Kecamatan Pamijahan, Kabupaten Bogor. Pemilihan lokasi dilakukan secara purposive (sengaja) berdasarkan ketertarikan 
penulis pada pariwisata berbasis komunitas $($ Community-Based Tourism $=C B T)$. Adapun data dalam penelitian ini dikumpulkan dengan menggunakan beberapa teknik yaitu pengumpulan dokumen, pengamatan, wawancara mendalam, dan diskusi kelompok. Waktu pelaksanaan penelitian selama 6 bulan yaitu sejak bulan Januari hingga Juni 2021. Metode analisis data disesuaikan dengan aspek yang dikaji seperti dijelaskan pada Tabel 1.

Tabel 1 Teknik Pengumpulan dan Analisis Data

\begin{tabular}{lllll}
\hline No & Aspek yang dikaji & $\begin{array}{l}\text { Metode } \\
\text { Pengumpulan Data }\end{array}$ & $\begin{array}{l}\text { Metode Analisis } \\
\text { Data }\end{array}$ & Data yang diperlukan \\
\hline 1 & Identifikasi konflik & $\begin{array}{l}\text { Wawancara } \\
\text { mendalam, } \\
\text { Observasi }\end{array}$ & Analisis deskriptif & $\begin{array}{l}\text { Isu-isu konflik, tahapan } \\
\text { konflik, akibat konflik }\end{array}$ \\
2 & $\begin{array}{l}\text { Analisis Stakeholder } \\
\text { (pemetaan aktor- } \\
\text { aktor) }\end{array}$ & $\begin{array}{l}\text { Wawancara } \\
\text { Mendalam }\end{array}$ & Analisis deskriptif & $\begin{array}{l}\text { Pemetaan aktor-aktor } \\
\text { yang terlibat }\end{array}$ \\
$\begin{array}{l}\text { Merumuskan } \\
\text { manajemen konflik }\end{array}$ & $\begin{array}{l}\text { Wawancara } \\
\text { mendalam, FGD }\end{array}$ & Analisis deskriptif & $\begin{array}{l}\text { Identifikasi konflik, } \\
\text { pemetaan aktor-aktor } \\
\text { konflik }\end{array}$ \\
\hline
\end{tabular}

Dalam memahami konflik yang terjadi pada komunitas wisata desa Curug Cikuluwung, dilakukan analisis konflik yang meliputi; identifikasi urutan kejadian konflik, identifikasi isuisu konflik, pemetaan aktor-aktor yang terlibat dalam konflik, identifikasi tahapan konflik yang terjadi, dan identifikasi akibat konflik (Fisher et al., 2001). Analisis stakeholders yang terlibat dalam konflik akan dianalisis menggunakan metode atau teori stakeholder salience (Mitchell et al., 1997) berdasarkan tiga atribut yakni: kekuasaan (power), legitimasi (legitimacy), dan urgensinya (urgency). Kekuasaan merupakan atribut yang menunjukkan seberapa besar stakeholder tersebut memiliki pengaruh. Atribut legitimasi mengindikasikan seberapa jauh stakeholder memiliki kewenangan atau diakui oleh masyarakat, serta atribut urgensi menunjukkan seberapa besar desakan stakeholder tersebut terhadap komunitas.

Engel dan Korf (2005) menjelaskan ragam pengelolaan konflik kontinum berupa: avoidance (menghindar): tindakan yang mencegah atau menghindar terjadinya konflik, negotiation (negosiasi): proses tawar-menawar yang dilakukan secara sukarela oleh pihak yang berkonflik untuk mencapai kesepakatan melalui consensus (keputusan yang bisa diterima oleh semua pihak), mediation (mediasi): menggunakan pihak ketiga untuk memfasilitasi proses negosiasi, pihak mediator tidak memiliki otoritas untuk memaksakan keputusan, arbitration (arbitrasi): menyerahkan penyelesaian konflik kepada pihak ketiga, yang akan membuat keputusan bagi pihak yang berkonflik, meski seringkali tidak bersifat mengikat, adjudication (adjudikasi): bersandar pada keputusan hakim atau administrator untuk membuat keputusan yang mengikat.

Sejalan dengan itu, Kinseng et al. (2013) menyatakan bahwa beragam pendekatan pengelolaan konflik yang dikemukakan oleh Engel dan Korf pada dasarnya sama dengan yang dikemukakan oleh Castro dan Nielsen yang menjelaskan bahwa prosedur mendasar dalam menangani konflik terdiri atas enam metode, yakni; avoidance (penghindaran) yaitu tindakan untuk menjaga agar konflik tidak muncul secara terbuka, coercion (pemaksaan) yaitu tindakan pemaksaan kehendak seseorang melalui ancaman atau kekuatan, termasuk kekerasan, protes, dominasi ekonomi, dan kontrak politik, negotiation (negosiasi), yaitu mengikuti proses secara sukarela yang mana pihak berkonflik mencapai kesepakatan melalui konsensus, mediation (mediasi), yaitu menggunakan pihak ketiga untuk memfasilitasi proses negosiasi, arbitration (arbitrasi), menyerahkan konflik kepada pihak ketiga yang disepakati, 
yang akan membuat keputusan, dan adjudication (ajudikasi), yaitu menyandarkan pada hakim atau administrator untuk membuat keputusan yang mengikat.

\section{HASIL DAN PEMBAHASAN}

\section{STRUKTUR SOSIAL}

Struktur sosial, menggambarkan dasar pelapisan sosial di Desa Cibitung Wetan, dan menggambarkan mobilitas sosial yang terjadi antar pelapisan sosial tersebut. Pelapisan sosial pada komunitas Desa Cibitung Wetan berdasarkan pada nilai ekonomis atau dalam hal ini adalah dalam penguasaan lahan dan berdasarkan pada ketokohan. Pelapisan sosial yang dikategorikan berdasarkan penguasaan lahan pertanian ini meliputi lahan yang dimiliki petani, lahan yang dikelola petani, dan lahan yang di sewa petani, dimana terbagi menjadi penguasaan lahan $<0.1$ ha (lapisan bawah), 0.1 ha -0.2 ha (lapisan menengah), 0.2 ha -0.3 ha (lapisan atas). Adapun karakteristik pemanfaatan hasil produksi tani berdasarkan penguasaan lahan meliputi:

1. 0.2 ha -0.3 ha (lapisan atas) memiliki asset yg cukup luas, lahan disewakan, atau menggunakan jasa buruh untuk mengelola lahan, tujuan utamanya produksi untuk dijual dan untuk memenuhi kebutuhan sehari-hari. Tokoh yang berada di lapisan atas ini adalah petani pemilik lahan dan tengkulak, seperti yang disampaikan oleh informan,

2. $0.1-0.2$ (lapisan menengah) memiliki lahan yang tidak terlalu luas, lahan ada yang di kelola/ di kerjakan oleh buruh tani, tujuan utamanya adalah untuk memenuhi kebutuhan sehari-hari,

3. $<0.1$ ha (lapisan bawah) meliputi penguasaan lahan yang minim yang biasanya milik orang lain yang diminta dikelola oleh para buruh tani, sistem pemberian upah harian dan atau dibagi hasil dengan proporsi 1:5 setiap kali panen (ngepak).

Ketokohan begitu di pandang, khususnya dalam pengambilan keputusan dan pemecahan masalah.

1. Tokoh yang berada pada tingkat tertinggi adalah tokoh dari pemerintahan desa dalam hal ini adalah Kepala Desa. Masyarakat akan lebih mendengarkan Kepala Desa dibandingkan tokoh agama, karena Kepala Desa kharismanya sampai ke luar Desa Cibitung Wetan. Selain Kepala Desa, penghormatan terhadap pemerintahan Desa ini juga berlaku untuk jajarannya, bahkan untuk ketua RT, beberapa Ketua RT di Desa Cibitung Wetan usianya sudah tidak muda lagi dan lulusan SD tetapi karena karisma ketokohannya mereka masih menjabat sebagai Ketua RT.

2. Tokoh agama dan tokoh pendidikan. Masyarakat akan lebih mendengarkan Kepala Desa dibandingkan tokoh agama, karena tokoh agama yang ada hanya memiliki nama di wilayahnya saja, beliau dikenal ke wilayah lain di Desa Cibitung Wetan karena diajak oleh pemerintahan desa dalam kegiatan tarawih keliling.

\section{ANALISIS KONFLIK}

Seiring dengan berkembangnya wisata desa Curug Cikuluwung, konflik pun terjadi pada pengembangan wisata desa Curug Cikuluwung. Untuk memahami bagaimana konflik tersebut terjadi, dilakukan analisis yang meliputi identifikasi urutan kejadian konflik, identifikasi isuisu konflik, pemetaan konflik, identifikasi tahapan konflik, dan identifikasi akibat dari konflik (Suryadi, Dharmawan \& Barus, 2020).

\section{Urutan Kejadian Konflik}

Dalam memahami konflik yang terjadi pada pengembangan wisata Desa Cibitung Wetan, akan digambarkan urutan kejadian konflik yang terjadi. Curug Cikuluwung merupakan wisata desa yang terdapat di Desa Cibitung Wetan yang keberadaannya baru diketahui oleh 
masyarakat sekitar lokasi Curug Cikuluwung. Lokasi Curug Cikuluwung yang mudah diakses mengakibatkan banyaknya wisatawan yang berkunjung ke wisata desa Curug Cikuluwung walaupun lokasi wisata tersebut baru dibuka untuk umum. Keberadaan Curug Cikuluwung diketahui oleh masyarakat sekitar pada awal tahun 2018, kemudian mereka membuat akses jalan menuju air terjun dan dibuka untuk umum pada pertengahan Januari tahun 2018. Dalam perjalanannya, pengelolaan wisata desa Curug Cikuluwung menemui beberapa permasalahan yang mengakibatkan terjadinya konflik baik di antara masyarakat maupun dengan pemerintahan desa.

Konflik pertama dalam pengembangan wisata desa Cibitung Wetan ini terjadi karena perebutan akses pintu masuk ke Curug Cikuluwung. Wisata Desa Cibitung Wetan memiliki objek wisata berupa air terjun. Masyarakat sekitar menyebut objek wisata tersebut dengan sebutan curug 1 dan curug 2. Untuk menuju objek wisata desa Curug Cikuluwung, terdapat beberapa jalan masuk. Selain dapat diakses dari Desa Cibitung Wetan, Curug Cikuluwungpun dapat diakses dari desa tetangga yakni Desa Pamijahan. Oleh karena itu, masyarakat Desa Pamijahan berinisiatif membuka loket masuk ke Curug Cikuluwung, di luar loket resmi.

Dikarenakan wisata desa Curug Cikuluwung memiliki potensi ekonomi yang tinggi, maka muncul ormas/LSM (Gempar) yang berada di sekitar wisata desa ini ingin memperoleh bagian dari uang tiket masuk ke Curug Cikuluwung. Konflik akses pintu masuk ke Curug Cikuluwung ini menjadi jalan bagi ormas/LSM untuk terlibat dalam konflik wisata desa Curug Cikuluwung. warga Desa Pamijahan (desa tetangga) yang membuka akses masuk ke Curug Cikuluwung (baca Mami) dari Curug 2 diadvokasi oleh ormas/LSM tersebut agar dia tetap bisa membuka pintu masuk ke Curug Cikuluwung dari Curug 2. Konflik ini cukup serius sehingga pemerintahan desa Cibitung Wetan dan Kapolsek Cibungbulang memfasilitasi pengelola Curug Cikuluwung beserta BUMDes membereskan konflik tersebut. Warga Desa Pamijahan (Mami) memberikan uang sebanyak 35 juta rupiah kepada LSM Gempar untuk mengadvokasi agar dia tetap bisa membuka pintu masuk ke wisata desa Curug Cikuluwung dari Curug 2. Ormas/LSM Gempar tersebut datang ke kantor Desa Cibitung Wetan mengatasnamakan masyarakat untuk menutup wisata desa Curug Cikuluwung. Pada Musyawarah tersebut hadir BUMDes Cibitung Wetan, Ketua Pengelola wisata desa Curug Cikuluwung, Mami (warga Desa Pamijahan), Ormas/LSM Gempar, Kepala Desa Cibitung Wetan dan Kapolsek Cibungbulang. Adanya dialog antara Pemerintahan Desa Cibitung Wetan dan ormas/LSM Gempar yang menyatakan bahwa pemerintahan desa memonopoli wisata desa tersebut dan menanyakan ijin membuka wisata desa Curug Cikuluwung, menghasilkan keputusan bahwa warga Desa Pamijahan (Mami) tetap bisa membuka akses masuk ke Curug Cikuluwung dari Curug 2 selama satu tahun sebagai kompensasi atas investasi yang dikeluarkan untuk membangun pintu akses ke wisata Desa Curug Cikuluwung dan ormas/LSM Gempar mendapatkan bagian dari tiket masuk ke Curug Cikuluwung. Konflik ini sudah ada solusinya, hubungan Mami dengan komunitas Curug Cikuluwung dan pemerintahan desa pun saat ini terjalin baik.

Wisata Desa Curug Cikuluwung berada di lahan PLN (PT Indonesia Power), agar wisata desa ini legal pemerintahan desa beserta BUMDes mengurus perijinan pembukaan wisata desa Curug Cikuluwung ke PT Indonesia Power Saguling.

Wisata Desa Curug Cikuluwung terus berkembang, pengunjung yang datang ke Curug Cikuluwung pun semakin banyak. Namun dalam masa perkembangannya, ketua pengelola Curug Cikuluwung mengundurkan diri, sehingga ketua pengelola diganti oleh pengurus lain yang merupakan salah seorang dari pelopor pembuka wisata desa Curug Cikuluwung. Dalam masa transisi pergantian kepengurusan, terjadi penyalahgunaan wewenang oleh Ketua BUMDes terhadap pengelolaan wisata Desa Curug Cikuluwung. Wisata desa Curug Cikuluwung merupakan salah satu bagian dari unit usaha BUMDes di bidang pariwisata. Kejadian tersebut membuat hilangnya kepercayaan pengurus wisata desa Curug Cikuluwung terhadap BUMDes dan pemerintahan desa, walaupun penyalahgunaan wewenang yang 
dilakukan oleh Ketua BUMDes di luar sepengetahuan pemerintahan desa. Peristiwa tersebut membuat pengelola wisata desa Curug Cikuluwung memutuskan untuk keluar dari unit usaha BUMDes, meskipun ketua BUMDes sudah diganti.

Keputusan ketua pengelola Curug Cikuluwung keluar dari BUMDes rupanya tidak disetujui oleh semua komunitas Curug Cikuluwung. Oleh karena itu, pengelola Curug Cikuluwung kemudian mengadakan musyawarah dengan pemerintahan desa, namun dalam pertemuan tersebut tidak semua pengurus hadir hanya diwakilkan oleh beberapa orang saja tanpa pengurus inti. Dalam musyawarah tersebut disepakati pembagian uang tiket yang masuk ke pengelola wisata desa Curug Cikuluwung dan ke PAD desa, juga adanya pengalokasian dari Dana Desa untuk pengembangan wisata desa Curug Cikuluwung. Pengurus inti Curug Cikuluwung ternyata tidak setuju dengan kesepakatan pembagaian uang tiket dengan pemerintahan desa sehingga menarik kembali kesepakatan tersebut dan memilih untuk tidak terkait dengan pemerintahan desa. Dikarenakan keputusan tersebut, akhirnya pemerintahan desa melalui musyawarah khusus mengalihkan alokasi Dana Desa yang sebelumnya akan dialokasikan untuk pengembangan wisata desa Curug Cikuluwung ke wisata desa lainnya. Adapun urutan kejadian konflik tersebut dijelaskan dalam Tabel 2.

Tabel 2 Urutan Kejadian Konflik Wisata Desa Curug Cikuluwung

\begin{tabular}{|c|c|}
\hline Waktu & Kejadian \\
\hline Januari 2018 & Wisata desa Curug Cikuluwung dibuka \\
\hline Januari - April 2018 & Pengelola melakukan promosi \\
\hline Juni 2018 & $\begin{array}{l}\text { Pengelola menghubungi pemerintahan } \\
\text { Desa }\end{array}$ \\
\hline Juli 2018 & $\begin{array}{l}\text { BUMDes menghubungi pengelola wisata } \\
\text { desa Curug Cikuluwung }\end{array}$ \\
\hline Agustus 2018 & $\begin{array}{l}\text { Curug Cikuluwung bergabung di unit } \\
\text { wisata desa BUMDes Cibitung Wetan }\end{array}$ \\
\hline Oktober 2018 & $\begin{array}{l}\text { BUMDes menutup pintu akses ke Curug } \\
\text { Cikuluwung dari desa tetangga dan } \\
\text { terjadilah konflik antara warga dari desa } \\
\text { lain dengan pengurus Curug Cikuluwung }\end{array}$ \\
\hline Oktober 2018 & $\begin{array}{l}\text { Pemerintahan Desa, Kapolsek, dan } \\
\text { BUMDes menyelesaikan konflik } \\
\text { pengelola Curug Cikuluwung dengan } \\
\text { warga dari desa lain yang membuka akses } \\
\text { masuk ke curug dari desanya dan LSM }\end{array}$ \\
\hline Desember 2018 & $\begin{array}{l}\text { Pemerintahan Desa dan BUMDes } \\
\text { mengurus perijinan ke PT Indonesia } \\
\text { Power Jawa Barat di Saguling }\end{array}$ \\
\hline Mei 2019 & $\begin{array}{l}\text { Ketua Pengelola mengundurkan diri dari } \\
\text { kepengurusan }\end{array}$ \\
\hline Mei 2019 & $\begin{array}{l}\text { Otomatis ada pergantian pengelola yang } \\
\text { baru yang saat ini menjabat }\end{array}$ \\
\hline Juli 2019 & $\begin{array}{l}\text { Terjadi penyalahgunaan wewenang oleh } \\
\text { Ketua BUMDes }\end{array}$ \\
\hline September 2019 & $\begin{array}{l}\text { Pengelola Curug Cikuluwung keluar dari } \\
\text { Unit Bisnis BUMDes }\end{array}$ \\
\hline Oktober 2019 & $\begin{array}{l}\text { Pengelola membuat kesepakatan dengan } \\
\text { pemerintahan Desa }\end{array}$ \\
\hline Desember 2019 & Pengelola menarik kesepakatan tersebut \\
\hline
\end{tabular}




\section{Identifikasi Isu-isu Konflik}

Dalam memetakan isu-isu konflik, peneliti menggunakan pohon konflik yang berdasarkan pada penyebab (berupa akar), masalah inti (berupa batang pohon), dan efek dari konflik (berupa ranting-ranting) tersebut. Berdasarkan urutan kejadian konflik, ada tiga konflik yang terjadi dalam pengembangan wisata desa Curug Cikuluwung.

Identifikasi isu-isu konflik pada konflik pertama. Berdasarkan hasil identifikasi pada konflik pertama, hal-hal yang melatarbelakangi konflik pertama pada pengembangan wisata desa Cibitung Wetan ini adalah penutupan pintu akses masuk ke wisata desa Curug Cikuluwung yang dibuka oleh warga Desa Pamijahan (Mami) oleh BUMDes Cibitung Wetan. Inti dari konflik ini adalah perebutan akses masuk ke wisata Curug Cikuluwung. Adapun efek dari konflik ini adalah warga Desa Pamijahan diijinkan membuka akses pintu masuk ke wisata desa Curug Cikuluwung oleh BUMDes, pengelola wisata Curug Cikuluwung dan Pemerintahan Desa Cibitung Wetan serta LSM/Ormas Gempar memperoleh bagian dari tiket masuk ke wisata desa Curug Cikuluwung, sebagaimana digambarkan pada Gambar 1.

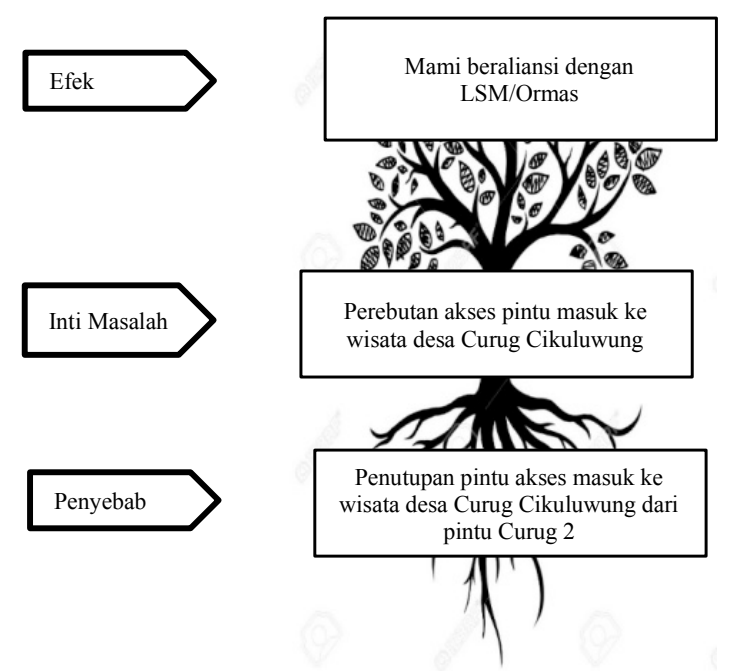

Gambar 1. Pohon konflik dalam Pengembangan Wisata Desa Cibitung Wetan antara BUMDes dan warga Desa Pamijahan (konflik pertama)

Identifikasi isu-isu konflik pada konflik kedua. Adapun, hal-hal yang melatarbelakangi konflik kedua pada pengembangan wisata desa Curug Cikuluwung adalah adanya penyalahgunaan jabatan oleh Ketua BUMDes yang lama sehingga menimbulkan hilangnya kepercayaan terhadap lembaga BUMDes, adanya prasangka dari pengelola wisata Desa Curug Cikuluwung kepada pemerintahan desa, adanya komunikasi yang tidak lancar antara pengurus Curug Cikuluwung dengan pemerintahan desa sehingga tidak adanya titik temu antara pengelola Curug Cikuluwung dengan pemerintahan desa, adanya isu politik yakni ketua pengelola Curug Cikuluwung merupakan pendukung calon kepala desa yang kalah dari kepala desa terpilih sehingga adanya provokasi dari mantan kandidat kepala desa tersebut, sumber daya manusia yang belum mampu mengelola wisata desa Curug Cikuluwung dengan profesional. Isu yang menjadi inti dari konflik pengembangan wisata desa Curug Cikuluwung adalah ketidaksepahaman antara pengelola inti wisata desa Curug Cikuluwung dengan Pemerintahan Desa Cibitung Wetan. Adapun efek dari konflik ini yaitu pengembangan wisata desa Curug Cikuluwung mengalami keterlambatan, pengurus Curug Cikuluwung tidak mendapatkan akses untuk memperoleh pelatihan, pengelola kesulitan mendapatkan akses untuk memperoleh bantuan dari pemerintah karena telah melepaskan keterikatan dari pemerintahan desasebagaimana tergambar dalam Gambar 2. 


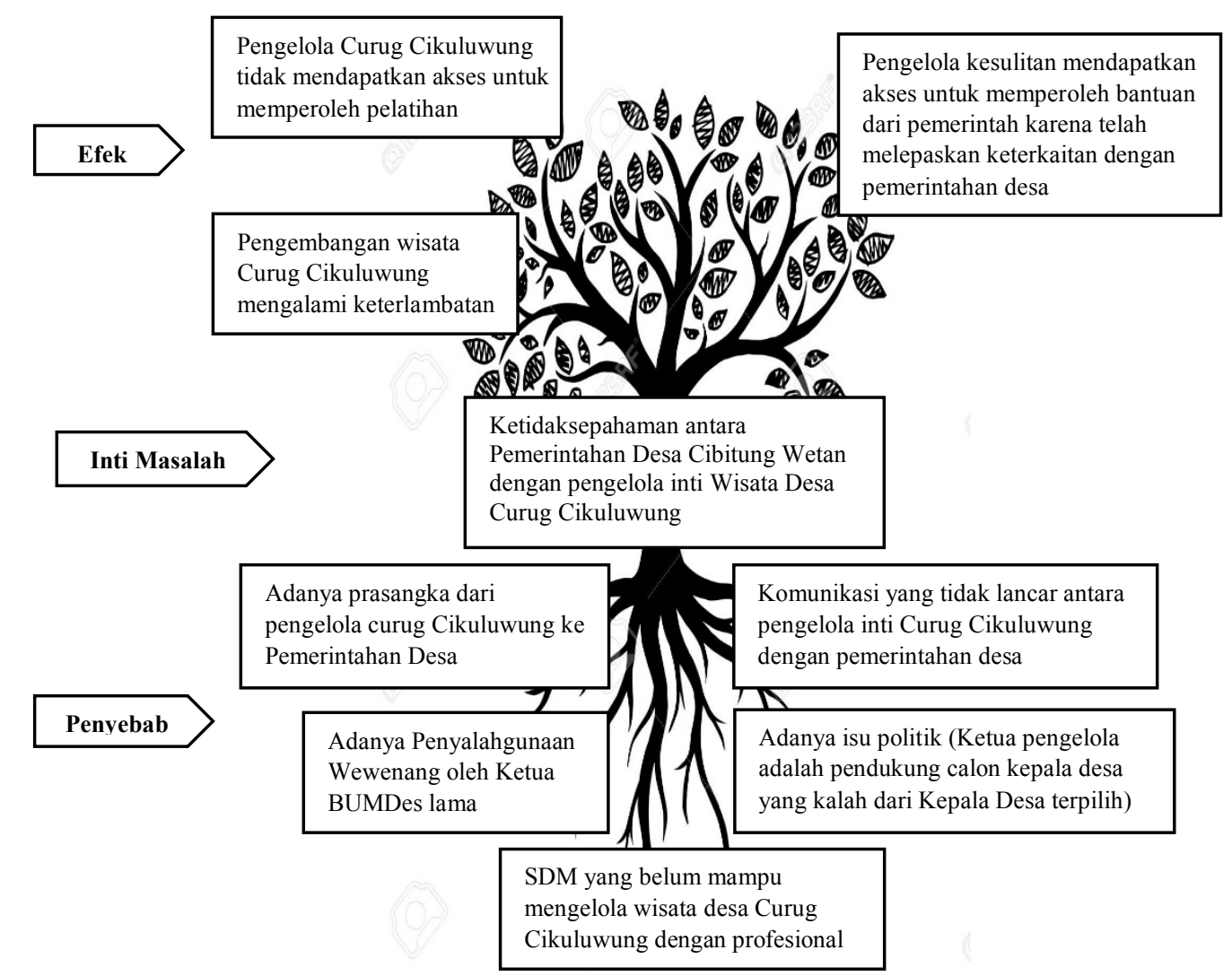

Gambar 2. Pohon Konflik dalam Pengembangan Wisata Desa Cibitung Wetan antara pengelola inti wisata desa Curug Cikuluwung dan Pemerintahan Desa Cibitung Wetan (konflik kedua)

Keterkaitan Isu antar Konflik. Dari kedua konflik yang terjadi dalam pengembangan wisata Desa Cibitung Wetan terdapat isu-isu konflik yang saling terkait yakni isu ekonomi sebagaimana tergambar pada Gambar 3. Konflik pertama antara BUMDes dan Mami (warga Desa Pamijahan) berkaitan dengan isu ekonomi yang termasuk ke dalam konflik realistic. Adapun, konflik kedua antara pengelola inti wisata desa Curug Cikuluwung dan pemerintahan Desa Cibitung Wetan ada dua isu konflik sekaligus yakni isu ekonomi dan isu politik yang merupakan konflik realistic sekaligus konflik non-realistic. 

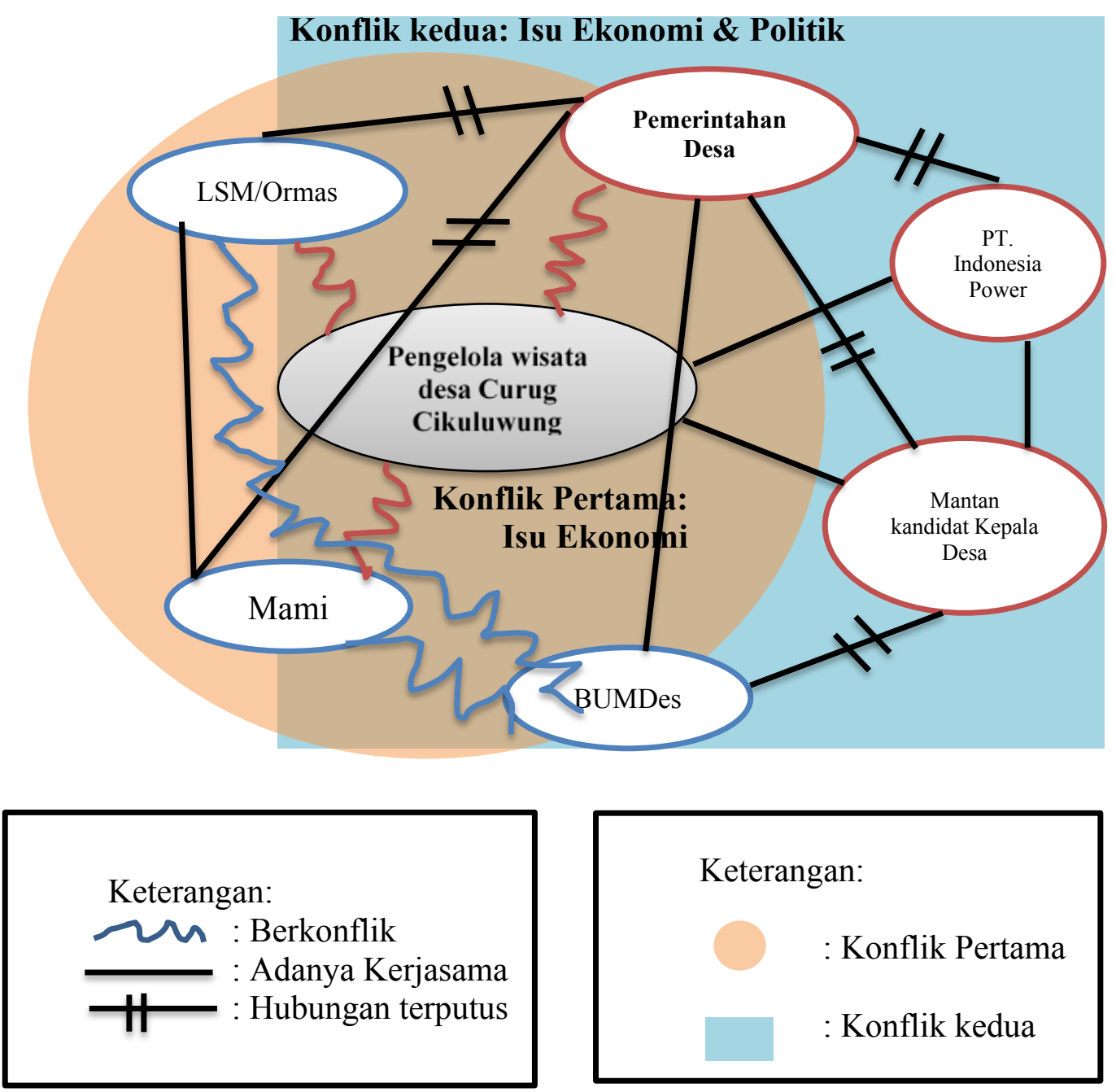

Gambar 3 Analisis antar kasus konflik

Menurut Coser konflik realistic akan berhenti jika aktor dapat menemukan alternatif yang sama-sama memuaskan dalam mencapai tujuannya sehingga konflik realistik lebih mudah diselesaikan dibandingkan dengan konflik non-realistic (Coser, 1964). Hal ini terbukti dalam penyelesaian konflik pertama dimana konflik pertama lebih cepat selesai dibandingkan dengan konflik kedua. Pada konflik pertama yang merupakan perebutan akses pintu masuk ke lokasi wisata desa adalah isu ekonomi, konflik berhasil dimediasi dalam waktu yang relatif lebih cepat, diselesaikan melalui mediasi dengan kesepakatan warga desa Pamijahan (Mami) tetap bisa membuka pintu masuk ke wisata desa Curug Cikuluwung, LSM/Ormas Gempar mendapatkan bagian dari tiket masuk dan pengelola wisata desa Curug Cikuluwung bisa membuka tempat wisata tanpa diganggu oleh kegaduhan dari LSM/Ormas yang selama ini menuntut bagian dari biaya tiket masuk.

Adapun untuk konflik kedua yang mana terdapat dua isu yakni isu ekonomi dan isu politik, realistic sekaligus non-realistic conflict ini lebih sulit untuk diselesaikan karena isu politiknya tersebut. Hubungan pemerintahan desa dengan pengelola inti wisata desa Curug Cikuluwung yang merupakan tim sukses dari mantan kandidat kepala desa rival kepala desa saat ini kurang harmonis, terlebih ketika ada penyalahgunaan jabatan oleh ketua BUMDes menjadi kesempatan bagi mantan rival kepala desa tersebut untuk memprovokasi pengelola agar keluar dari BUMDes yang berujung pengelola wisata desa Curug Cikuluwung memutuskan mengelola sendiri tanpa bantuan dari pemerintahan desa 


\section{Pemetaan Aktor-Aktor yang Terlibat dalam Konflik}

Hubungan aktor yang terlibat dalam konflik akan terlihat apabila dilakukan pemetaan konflik. Pemetaan konflik ini dilakukan di antaranya untuk lebih memahami situasi dengan baik, untuk melihat hubungan di antara berbagai pihak secara lebih jelas, untuk menjelaskan di mana letak kekuasaan, untuk memeriksa keseimbangan masing-masing kegiatan atau reaksi, untuk melihat para sekutu atau sekutu yang potensial berada di mana dan untuk mengevaluasi apa yang telah dilakukan.

Pemetaan Aktor-aktor yang terlibat dalam konflik pertama. Berdasarkan pemetaan aktoraktor yang terlibat dalam konflik pertama yakni konflik antara BUMDes dan warga desa tetangga yakni Desa Pamijahan (Mami) diperoleh beberapa aktor yang terlibat, yakni: BUMDes, Pengelola wisata desa Curug Cikuluwung, Mami, dan LSM/Ormas Gempar. Konflik ini sudah selesai dimediasi oleh Pemerintahan Desa Cibitung Wetan dan Kapolsek Cibungbulang. Selanjutnya hubungan antar aktor dijelaskan pada Tabel 3 dan Gambar 4.

Tabel 3 Aktor-aktor yang terlibat dalam konflik Curug Cikuluwung pertama

\begin{tabular}{|c|c|c|}
\hline No & $\begin{array}{l}\text { Pihak-pihak yang } \\
\text { terlibat Konflik }\end{array}$ & Kepentingan atas Wisata Desa Curug Cikuluwung \\
\hline 1 & $\begin{array}{l}\text { Pengelola wisata desa } \\
\text { Curug Cikuluwung }\end{array}$ & Pengelola wisata desa Curug Cikuluwung \\
\hline 2 & Mami & Warga Desa Pamijahan (desa tetangga) \\
\hline 3 & BUMDes Cikahuripan & $\begin{array}{l}\text { Badan Usaha Milik Desa yang mengelola unit bisnis yang } \\
\text { terdapat di Desa Cibitung Wetan, termasuk unit pariwisata }\end{array}$ \\
\hline 4 & LSM & $\begin{array}{l}\text { Ingin memperoleh bagian dari tiket masuk ke wisata desa } \\
\text { Curug Cikuluwung }\end{array}$ \\
\hline 5 & Pemerintahan Desa & $\begin{array}{l}\text { Sebagai pemangku kebijakan Desa Cibitung Wetan dalm } \\
\text { konflik ini berperan sebagai mediator }\end{array}$ \\
\hline 6 & $\begin{array}{l}\text { Kapolsek } \\
\text { Cibungbulang }\end{array}$ & $\begin{array}{l}\text { Sebagai Kepolisian Sektor Kecamatan Cibungbulang sekaligus } \\
\text { untuk wilayah Kecamatan Pamijahan dalam konflik ini } \\
\text { berperan sebagai mediator }\end{array}$ \\
\hline
\end{tabular}

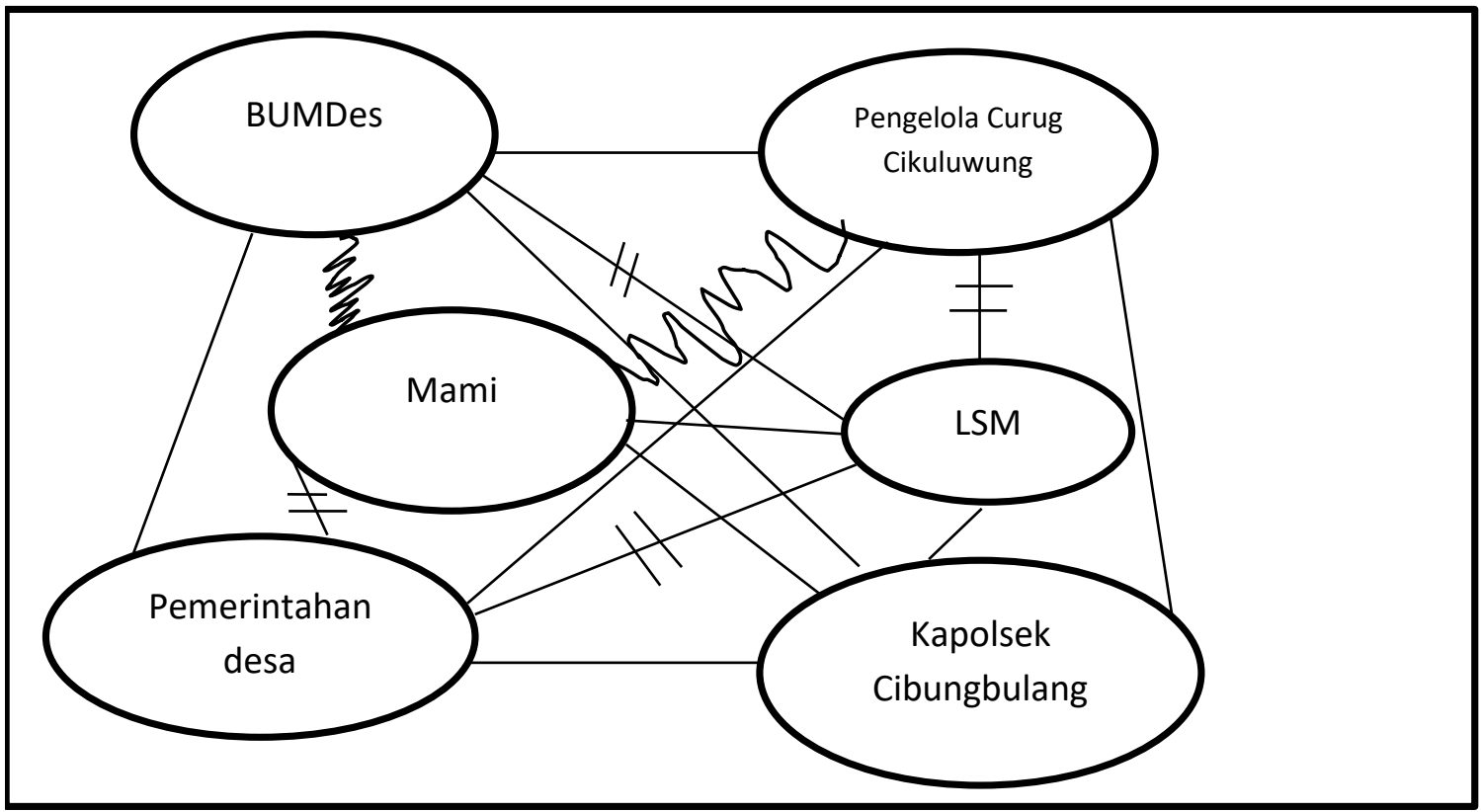

Gambar 4. Pemetaan aktor-aktor yang terlibat dalam konflik BUMDes dengan warga Desa Pamijahan (konflik pertama) 
Berdasarkan Gambar 4 tersebut garis lurus menunjukkan adanya kerjasama hal ini ditunjukkan oleh BUMDes dengan Pengelola Curug Cikuluwung, pemerintahan desa, Kapolsek Cibungbulang. Selain itu, adanya kerjasama juga ditunjukkan oleh pengelola wisata desa Curug Cikuluwung dengan BUMDes, pemerintahan desa dan Kapolsek Cibungbulang, kemudian antara Mami dan LSM, antara pemerintahan desa dan Kapolsek Cibungbulang, antara LSM dan Kapolsek Cibungbulang serta antara Kapolsek Cibungbulang dan Mami. Hubungan terputus ditunjukan oleh BUMDes dengan LSM, pengelola wisata desa Curug Cikuluwung dengan LSM, pemerintahan desa dengan Mami serta pemerintahan desa dengan LSM. Adapun yang berkonflik adalah BUMDes dengan Mami dan pengelola wisata desa Curug Cikuluwung dengan Mami.

Konflik ini terjadi karena adanya penutupan akses pintu masuk ke wisata desa Curug Cikuluwung dari pintu lainnya yang dibuka oleh warga Desa Pamijahan oleh BUMDes, dengan tujuan untuk mengintegrasikan akses pintu masuk ke lokasi wisata dari satu pintu utama yang resmi. Namun, konflik tersebut sudah selesai dengan win-win solution yang dimediasi oleh Pemerintahan Desa Cibitung Wetan dan Kapolsek Cibungbulang.

Pemetaan aktor-aktor yang terlibat dalam konflik kedua. Melalui identifikasi aktor yang terlibat dalam konflik pengembangan wisata Desa Cibitung Wetan kedua antara pengelola inti wisata desa Curug Cikuluwung dan pemerintahan Desa Cibitung Wetan, didapatkan beberapa aktor yakni; ketua dan wakil ketua pengelola Curug Cikuluwung (pengelola inti wisata desa Curug Cikuluwung), pemerintahan Desa Cibitung Wetan, BUMDes, PT Indonesia Power dan mantan kandidat kepala desa. Selanjutnya mengenai aktor-aktor yang terlibat tersebut lebih jelasnya dalam Tabel 4, dan hubungan antar stakeholder disajikan secara grafis pada Gambar 5.

Tabel 4. Aktor-aktor yang terlibat dalam konflik Curug Cikuluwung kedua

\begin{tabular}{|c|c|c|}
\hline No & $\begin{array}{l}\text { Pihak-pihak yang } \\
\text { terlibat Konflik }\end{array}$ & Kepentingan atas Wisata Desa Curug Cikuluwung \\
\hline 1 & $\begin{array}{l}\text { Pengelola inti wisata } \\
\text { desa Curug } \\
\text { Cikuluwung }\end{array}$ & $\begin{array}{l}\text { Pengelola wisata desa Curug Cikuluwung saat ini } \\
\text { merupakan pengurus baru dari wisata desa curug } \\
\text { cikuluwung yang merupakan pelopor wisata desa } \\
\text { Curug Cikuluwung }\end{array}$ \\
\hline 2 & $\begin{array}{l}\text { Pemerintahan Desa } \\
\text { Cibitung Wetan }\end{array}$ & $\begin{array}{l}\text { Pemerintahan Desa selaku pemangku kebijakan } \\
\text { wilayah Desa Cibitung Wetan }\end{array}$ \\
\hline 3 & BUMDes Cikahuripan & $\begin{array}{l}\text { Badan Usaha Milik Desa yang mengelola unit bisnis } \\
\text { yang terdapat di Desa Cibitung Wetan, termasuk unit } \\
\text { pariwisata }\end{array}$ \\
\hline 4 & PT Indonesia Power & $\begin{array}{l}\text { Pemilik lahan di mana lokasi Curug Cikuluwung } \\
\text { berada }\end{array}$ \\
\hline 5 & $\begin{array}{l}\text { Mantan kandidat } \\
\text { kepala desa }\end{array}$ & $\begin{array}{l}\text { Membantu pengelola inti wisata desa Curug } \\
\text { Cikuluwung yang merupakan tim sukses Ketika } \\
\text { pemilihan kepala desa }\end{array}$ \\
\hline
\end{tabular}




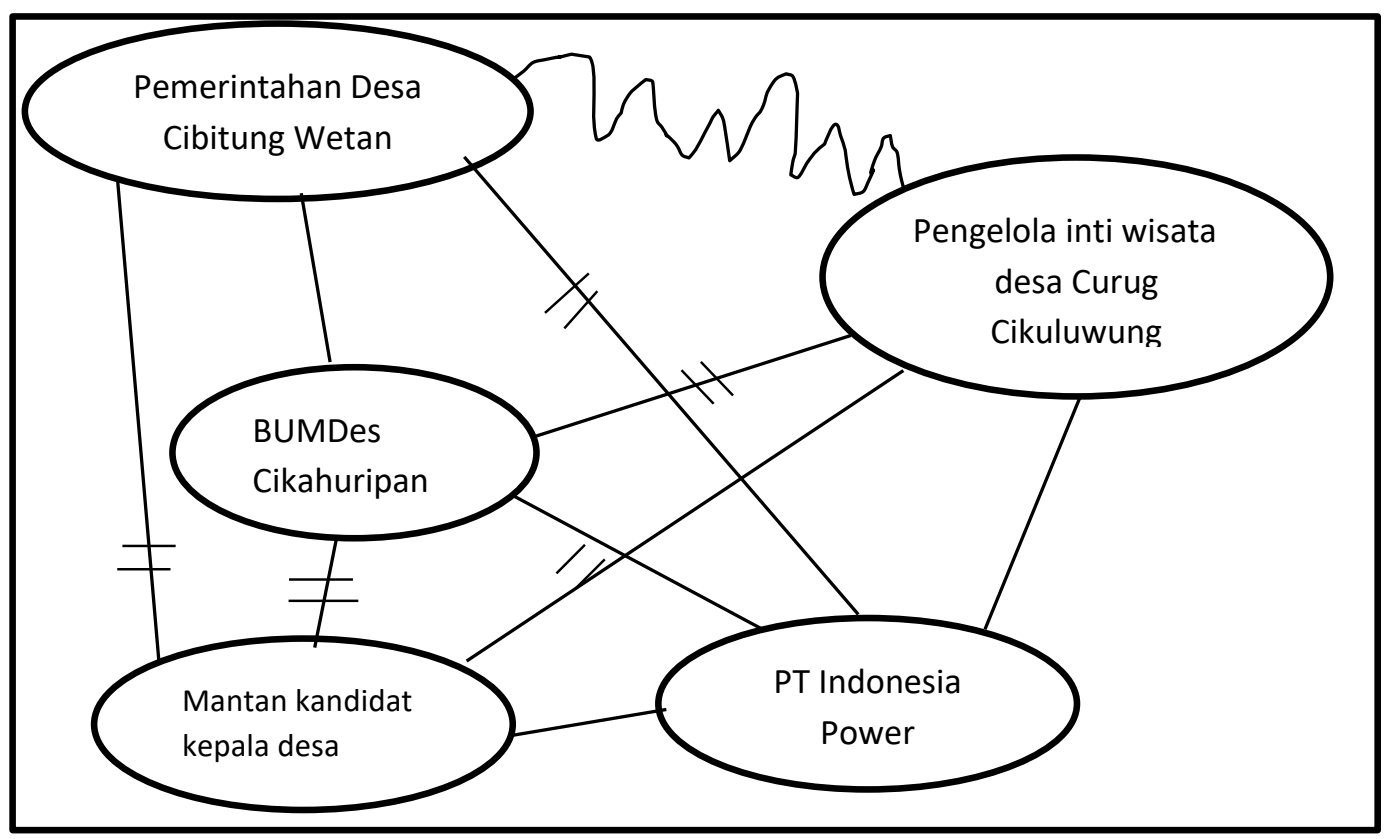

Gambar 5 Pemetaan aktor-aktor yang terlibat dalam konflik BUMDes dengan warga Desa Pamijahan (konflik kedua)

Berdasarkan Gambar 5 tersebut, garis lurus menunjukkan adanya kerjasama. Hal ini ditunjukkan dengan adanya kerjasama antara Pemerintahan Desa Cibitung Wetan dan BUMDes, kemudian antara pengelola inti wisata desa Curug Cikuluwung dan mantan kandidat kepala desa, antara pengelola inti wisata desa Curug Cikuluwung dan PT Indonesia Power serta antara mantan kandidat kepala desa dan PT Indonesia Power. Pengelola inti wisata desa Curug Cikuluwung berkonflik dengan Pemerintahan Desa Cibitung Wetan, sedangkan pengelola inti wisata desa Curug Cikuluwung memiliki hubungan yang terputus dengan BUMDes Cikahuripan. Kemudian Pemerintahan Desa Cibitung Wetan hubungannya terputus dengan PT Indonesia Power dan dengan mantan kandidat kepala desa, BUMDes Cikahuripan memiliki hubungan yang terputus dengan PT Indonesia Power dan mantan kandidat kepala desa.

\section{Identifikasi Tahapan Konflik}

Pada umumnya konflik berubah setiap saat, melalui berbagai tahap aktivitas, tahap-tahap ini penting untuk diketahui. Dari hasil pemetaan aktor-aktor yang terlibat dalam konflik dan wawancara dengan informan bisa dikatakan konflik yang terjadi pada wisata desa Cibitung Wetan yang pertama dan kedua adalah konflik terbuka karena sudah muncul ke permukaan atau terlihat dan beberapa orang di komunitas sudah mengetahuinya walaupun mereka ada yang tidak gamblang secara jelas menyatakan ada konflik antara pemerintahan desa dengan pengelola inti wisata desa Curug Cikuluwung seperti yang tergambar pada Gambar 6. Engel dan Korf (Engel \& Korf, 2005), menggambarkan tahapan konflik mulai dari laten, muncul ke permukaan hingga kekerasan (violent). Sejalan dengan itu, Kinseng et al. (2013) menyatakan bahwa konflik adalah relasi sosial antar aktor sosial yang ditandai oleh pertentangan atau perselisihan dan kemarahan, baik dinyatakan secara terbuka maupun tidak, dalam rangka mencapai keinginan atau tujuan masing-masing. 


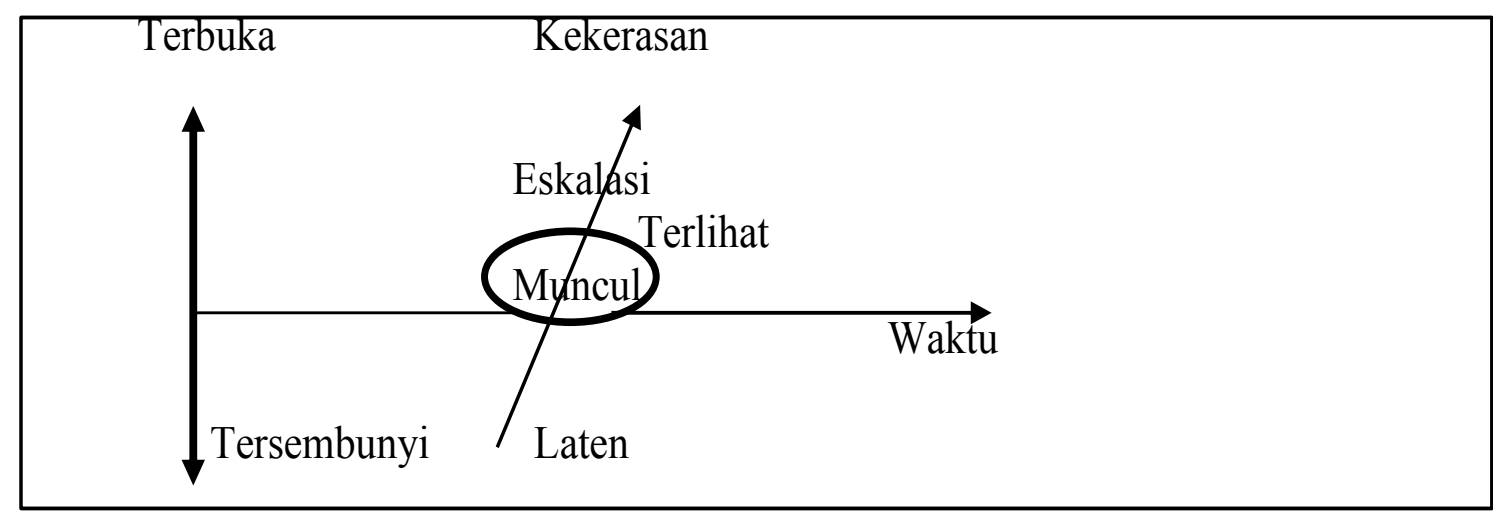

Gambar 6 Tahapan Konflik Wisata Desa Curug Cikuluwung merujuk Engel dan Korf

Sementara itu, Fisher (Fisher et al., 2001) membagi tahapan konflik menjadi lima tahap, yakni: Prakonflik, Konfrontasi, Krisis, Akibat, dan Pascakonflik. Tahapan konflik di wisata desa Curug Cikuluwung merujuk ke tahapan konflik menurut Fisher lihat Gambar 7, untuk konflik pertama berada pada tahap pascakonflik karena situasi diselesaikan dengan cara mengakhiri berbagai konfrontasi kekerasan, ketegangan berkurang dan hubungan mengarah ke lebih normal di antara kedua pihak sedangkan untuk konflik kedua berada pada tahap krisis, karena aktor-aktor yang berkonflik masing-masing teguh dengan pendirian mereka. Konflik saat ini terjadi berawal dari adanya penyalahgunaan wewenang oleh Ketua BUMDes yang lama, sehingga muncul rasa tidak percaya dari pengelola ke pemerintahan desa. Meskipun musyawarah sudah dilakukan dengan komunitas Curug Cikuluwung, namun pengurus inti tidak pernah bertemu secara langsung dengan pemerintahan desa.

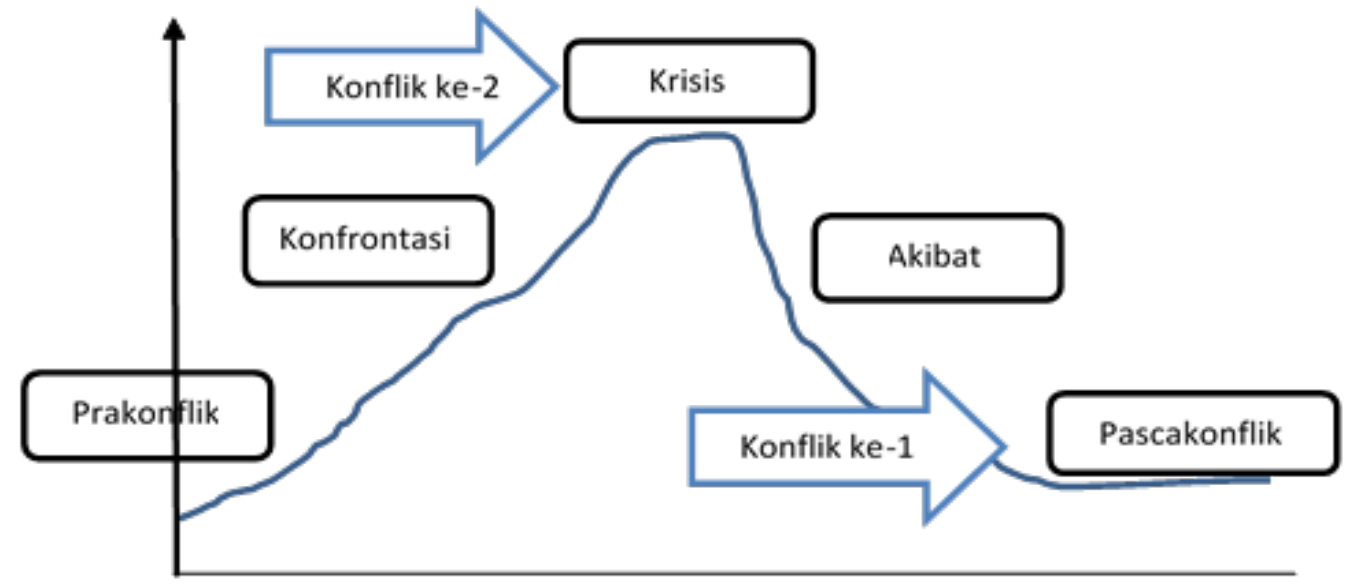

Gambar 7 Tahapan Konflik Wisata Desa Curug Cikuluwung merujuk Fisher

\section{Identifikasi Akibat Konflik}

Selanjutnya untuk identifikasi akibat konflik, akan menggunakan alat bantu analisis dari Lewis Coser yakni konflik konstruktif dan konflik destruktif. Konflik konstruktif adalah konflik yang "berfungsi positif", sebaliknya konflik destruktif adalah konflik yang mengakibatkan kerusakan bahkan kehancuran, baik harta benda maupun jiwa manusia (Kinseng et al., 2013).

Menurut Coser (1964), konflik memiliki dua fungsi yakni konflik konstruktif dan konflik destruktif. Konflik yang pertama merupakan konflik konstruktif karena setelah terjadi konflik hubungan kedua pihak yang berkonflik lebih baik. Pada konflik pertama hubungan pihak yang berkonflik menjadi lebih baik, dan menguntungkan semua pihak walaupun untuk pengelola 
wisata desa Curug Cikuluwung menjadi memiliki kewajiban untuk mengalokasikan sejumlah uang dari tiket masuk untuk bagian LSM/Ormas Gempar, tetapi wisata desa tetap bisa berjalan.

Adapun akibat konflik kedua yang terjadi di wisata desa Curug Cikuluwung merupakan konflik destruktif karena mengakibatkan terlambatnya pengembangan wisata desa Curug Cikuluwung, pengurus Curug Cikuluwung tidak mendapatkan akses untuk mengikuti pelatihan, pengelola tidak mendapatkan akses memperoleh bantuan dari pemerintah. Berdasarkan identifikasi akibat konflik di atas maka konflik kedua yang terjadi di wisata Desa Cibitung Wetan termasuk ke dalam konflik destruktif karena membuat wisata desa Curug Cikuluwung tidak berkembang bahkan cenderung mengalami kemunduran. Hal ini terlihat dari akses yang pengelola tidak peroleh baik pembiayaan maupun peningkatan kapasitas pengelola.

\section{ANALISIS STAKEHOLDERS}

Stakeholder yang terlibat dalam konflik ini terdiri dari Lembaga pemerintah, komunitas dan BUMN. Lembaga pemerintah yang terlibat dalam konflik ini adalah Pemerintahan Desa, BUMDes, dan Kapolsek Cibungbulang sedangkan komunitas atau masyarakat yang terlibat dalam konflik ini adalah Komunitas Curug Cikuluwung, Mami, LSM dan mantan kandidat kepala desa, serta BUMN adalah PT Indonesia Power. Dalam menganalisis stakeholders ini menggunakan teori stakeholder salience dari (Mitchell et al., 1997) sebagai berikut dan ringkasannya dijelaskan pada Tabel 5.

Tabel 5. Stakeholder pada konflik pengembangan wisata desa Curug Cikuluwung

\begin{tabular}{llll}
\hline Kelompok & Kekuasaan & Legitimasi & Urgensi \\
\hline Definitif & & Tinggi & Tinggi \\
Pemerintahan Desa Cibitung Wetan & Tinggi & Tinggi & Tinggi \\
Kapolsek Cibungbulang & Tinggi & & \\
Expectant/Pengharap & & Tinggi & Tinggi \\
Komunitas Curug Cikuluwung & Sedang & & \\
Laten & & Tinggi & Sedang \\
PT Indonesia Power & Sedang & Rendah & Sedang \\
BUMDes Cikahuripan Cibitung & Sedang & & \\
Wetan & & Rendah & Rendah \\
Mami (warga Desa Pamijahan) & Rendah & & \\
& & Rendah & Rendah \\
LSM & Rendah & Rendah & Rendah \\
Mantan Kandidat Kepala Desa & Rendah & & \\
\hline
\end{tabular}

Pemerintahan Desa Cibitung Wetan. Pemerintahan Desa merupakan penyelenggara pemerintahan dan pembangunan desa dimana wisata desa Curug Cikuluwung berada. Pemerintahan Desa sangat mendukung pengembangan wisata desa Curug Cikuluwung, 
bahkan sudah mempunyai rencana untuk mengembangkan wisata desa Curug Cikuluwung ini menjadi Desa Wisata Cibitung Wetan. Tujuan wisatanya akan berkesinambungan dari Curug Cikuluwung ke tujuan wisata lainnya yang ada dan yang akan dikembangkan oleh Pemerintahan Desa Cibitung Wetan dan BUMDes Cikahuripan. Namun ketika pengelolanya tidak mau terkait dengan pemerintahan desa maka pemerintahan desa pun tidak mau ikut campur dalam pengelolaan wisata desa Curug Cikuluwung. Adapun untuk nilai atribut Pemerintahan Desa Cibitung Wetan memiliki nilai yang tinggi untuk semua atribut, yakni untuk kekuatan, legitimasi dan urgensinya.

Komunitas Curug Cikuluwung. Komunitas Curug Cikuluwung terbentuk pada tahun 2018 setelah wisata desa ini dibuka untuk umum. Komunitas ini dibentuk oleh masyarakat sekitar wisata desa Curug Cikuluwung yang terdiri dari pengurus, pemandu, penjaga loket. Sampai saat ini sudah dua orang yang menjadi Ketua pengelola wisata desa Curug Cikuluwung. Komunitas wisata desa Curug Cikuluwung bergabung dengan BUMDes Cikahuripan Desa Cibitung Wetan pada bulan Agustus 2018. Pada saat bergabung dengan BUMDes pemandu wisata desa Curug Cikuluwung mengikuti pelatihan dari Dinas Kebudayaan dan Pariwisata Kabupaten Bogor. Untuk atribut kekuasaan, pengelola Curug Cikuluwung memiliki nilai yang sedang, sedangkan untuk atribut legitimasi dan urgensi, pengelola Curug Cikuluwung memiliki nilai yang tinggi.

Badan Usaha Milik Desa (BUMDes) Cikahuripan. BUMDes Cikahuripan merupakan usaha desa yang dikelola oleh pengurus di bawah pemerintahan desa. BUMDes ini dibentuk untuk mengelola kebutuhan dan potensi desa. Dalam BUMDes ini terdiri dari beberapa unit usaha, salahsatunya adalah unit pariwisata dimana wisata desa Curug Cikuluwung berada dalam unit usaha ini. BUMDes Cikahuripan dibentuk pada tahun 2018, pada masa pengembangannya Ketua BUMDes menyalahgunakan wewenang. Namun saat ini ketua BUMDes sudah diganti dan kepengurusannya pun diganti semua. Adapun untuk nilai atribut BUMDes akan kekuasaan dan legitimasi mempunyai nilai yang rendah sedangkan untuk urgensi memiliki nilai yang sedang.

Warga Desa Pamijahan (Mami). Adalah seorang warga dari desa tetangga yang berjualan di dekat lokasi Curug Cikuluwung, dan melihat potensi ekonomi sehingga dia membuka akses pintu masuk ke wisata desa Curug Cikuluwung dari pintu lainnya selain pintu utama. Nilai atribut kekuasaan, legitimasi dan urgensi dari Mami ini rendah.

LSM/Ormas Gempar. Merupakan organisasi masyarakat yang mengadvokasi Mami untuk tetap bisa membuka akses pintu masuk ke wisata desa Curug Cikuluwung dari pintu lainnya selain pintu Utama yang resmi dan mereka menginginkan ada bagian dari hasil penjualan tiket masuk ke wisata desa Curug Cikuluwung. Nilai atribut kekuasaan, legitimasi, dan urgensi untuk LSM ini adalah rendah.

Kapolsek Cibungbulang. Kapolsek Cibungbulang sekaligus Kapolsek Pamijahan selaku pengayom masyarakat dalam konflik ini berperan sebagai mediator. Nilai atribut kekuasaan, legitimasi dan urgensi untuk Kapolsek ini tinggi.

PT Indonesia Power (PLN). PT Indonesia Power merupakan BUMN pemilik lahan dimana lokasi wisata desa Curug Cikuluwung berada. Lokasi ini berada dalam wilayah kerja PLTA Kracak yang kantornya di Kecamatan Leuwiliang dan pusatnya di Saguling Rajamandala, Bandung Barat, Jawa Barat. Pengurus BUMDes yang lama dan Pemerintahan Desa Cibitung Wetan telah memfasilitasi komunitas wisata Desa Curug Cikuluwung untuk mengurus perijinan ke PT Indonesia Power di Rajamandala Bandung. Proses perijinan tersebut masih dalam proses review dari PT Indonesia Power dan karena ada permasalahan dari Ketua BUMDes yang lama sehingga pengurusan perijinan belum selesai. Saat ini perijinan pembukaan lokasi wisata dilakukan oleh pihak swasta yakni PT Akaraya. PT Indonesia Power memiliki nilai yang tinggi untuk atribut legitimasi sedangkan untuk atribut kekuatan dan urgensi memiliki nilai yang sedang. 
Mantan Kandidat Kepala Desa. Mantan kandidat kepala desa ini adalah orang di luar komunitas Curug Cikuluwung namun masih penduduk Desa Cibitung Wetan. Dia merupakan salah satu rival kepala desa yang saat ini menjabat pada saat pemilihan kepala desa. Mantan kandidat kepala desa ini merupakan relasi dekat dari Ketua Pengelola Komunitas Curug Cikuluwung saat ini yang pada saat pemilihan adalah tim suksesnya. Menurut pengelola mantan kandidat kepala desa ini yang sekarang membantu pengelola wisata desa Curug Cikuluwung untuk memperoleh perijinan ke PT Indonesia Power. Adapun nilai atribut untuk mantan kandidat kepala desa ini memiliki nilai yang rendah untuk kekuasaan, legitimasi, dan urgensinya.

Dilihat dari Tabel 5, Pemerintahan Desa Cibitung Wetan dan Kapolsek Cibungbulang memiliki nilai yang tinggi pada semua atribut sehingga masuk kelompok definitif, sedangkan komunitas Curug Cikuluwung memiliki kekuasaan yang sedang namun memiliki nilai yang tinggi pada atribut legitimasi dan urgensi sehingga masuk pada kelompok expectant (pengharap). Adapun BUMDes dan PT Indonesia Power, Mami, LSM/ormas Gempar dan mantan kandidat Kepala Desa masuk kelompok laten.

\section{MANAJEMEN KONFLIK}

Dalam pengembangan wisata desa tidak terlepas dari konflik termasuk dalam pengembangan wisata desa Curug Cikuluwung. Hal yang paling penting dalam pengelolaan sebuah konflik adalah mengakui dan mencari solusi untuk pengelolaan konflik tersebut. Konflik pertama pada pengembangan wisata desa Curug Cikuluwung sudah dikelola dengan baik yakni melalui mediasi pihak ketiga.

Dari beberapa upaya yang telah dilakukan untuk mencari solusi pengelolaan konflik, dan belum adanya kesepakatan sebagai solusi untuk konflik tersebut, sehingga perlu melibatkan pihak ketiga. Engel dan Korf menjelaskan lima ragam pengelolaan konflik berupa kontinum yakni avoidance (menghindar), negotiation (negosiasi), mediation (mediasi), arbitration (arbitrasi), adjudication (ajudikasi) (Engel \& Korf, 2005). Namun untuk manajemen konflik berbasis komunitas, pengelolaan konflik ini maksimal pada tahap mediasi karena sampai tahap ini solusi yang diperoleh win-win solution, berbeda dengan yang kedua terakhir solusi yang diperoleh win-lose solution.

Berdasarkan upaya-upaya yang sudah dilakukan oleh komunitas yakni avoidance dan negotiation maka untuk pengelolaan konflik kedua pada pengembangan wisata desa Curug Cikuluwung perlu adanya mediasi dari pihak ketiga. Sebagaimana yang dijelaskan sebelumnya, konflik kedua ini memiliki dua isu yakni isu ekonomi dan isu politik. Isu politik yang termasuk konflik non realistik memang lebih sulit untuk diselesaikan karena menyangkut identitas, dignity, pride, namun untuk isu ekonomi yang merupakan konflik realistik cenderung lebih mudah untuk diselesaikan. Isu politik yakni adanya pengaruh dari mantan rival kepala desa terhadap pengelola inti wisata desa Curug Cikuluwung dan isu ekonomi berkaitan dengan retribusi tiket masuk ke wisata desa Curug Cikuluwung. Dikarenakan kedua isu tersebut, pihak berwenang yang perlu memediasi pengelola inti wisata desa Curug Cikuluwung dengan pemerintahan desa Cibitung Wetan adalah pemerintahan Kecamatan Pamijahan dalam hal ini Kasi Ekonomi dan pembangunan dan Kasi PMD serta dari pemerintahan Kabupaten Bogor dalam hal ini Dinas Pariwisata dan Dinas Pemberdayaan Masyarakat Desa dan atau PT Indonesia Power selaku pemilik lahan dimana wisata desa berada.

Sejalan dengan hal ini, Kinseng menyatakan bahwa pemerintah memiliki peran mediasi yang penting untuk dilakukan dalam konflik antara penduduk lokal pulau Pari dan perusahaan (Kinseng et al., 2018). 


\section{KESIMPULAN}

Berdasarkan analisis konflik urutan kejadian konflik, sampai saat ini ada dua konflik yang terjadi dalam pengembangan wisata Desa Cibitung Wetan, yakni; konflik BUMDes dengan warga Desa Pamijahan, dan konflik antara pengelola inti wisata desa Curug Cikuluwung dan pemerintahan desa.

Adapun berdasarkan hasil identifikasi hal-hal yang melatarbelakangi konflik pertama pada pengembangan wisata desa Cibitung Wetan adalah penutupan pintu akses masuk ke wisata desa Curug Cikuluwung dari pintu lainnya yang dibuka warga desa tetangga (Desa Pamijahan) oleh BUMDes Cibitung Wetan. Inti dari konflik ini adalah perebutan akses masuk ke wisata Curug Cikuluwung. Adapun efek dari konflik ini adalah warga Desa Pamijahan diijinkan membuka akses pintu masuk ke wisata desa Curug Cikuluwung oleh BUMDes, pengelola wisata desa Curug Cikuluwung dan Pemerintahan Desa Cibitung Wetan serta LSM memperoleh bagian dari tiket masuk ke wisata desa Curug Cikuluwung.

Adapun hal-hal yang melatarbelakangi konflik kedua pada pengembangan wisata desa Curug Cikuluwung adalah adanya penyalahgunaan wewenang oleh Ketua BUMDes yang lama sehingga menimbulkan hilangnya kepercayaan terhadap lembaga BUMDes, adanya prasangka dari pengelola wisata Desa Curug Cikuluwung kepada pemerintahan desa, adanya komunikasi yang tidak lancar antara pengurus Curug Cikuluwung dengan pemerintahan desa sehingga tidak adanya titik temu antara pengelola Curug Cikuluwung dengan pemerintahan desa, adanya isu politik yakni ketua pengelola Curug Cikuluwung merupakan pendukung calon kepala desa yang kalah dari kepala desa terpilih, sumber daya manusia yang belum mampu mengelola wisata desa Curug Cikuluwung dengan profesional. Isu yang menjadi inti dari konflik pengembangan wisata desa Curug Cikuluwung adalah ketidaksepahaman antara pengelola inti wisata desa Curug Cikuluwung dengan Pemerintahan Desa Cibitung Wetan. Adapun efek dari konflik ini yaitu pengembangan wisata desa Curug Cikuluwung mengalami keterlambatan, pengurus Curug Cikuluwung tidak mendapatkan akses untuk memperoleh pelatihan, pengelola kesulitan mendapatkan akses untuk memperoleh bantuan dari pemerintah karena telah melepaskan ikatan dari pemerintahan desa.

Identifikasi konflik yang terjadi pada pengembangan wisata desa Curug Cikuluwung berdasarkan tahapannya ada pada tahap emerging dan paskakonflik untuk konflik pertama dan emerging dan krisis untuk konflik yang terakhir. Adapun akibat dari konflik pertama adalah konstruktif sedangkan untuk konflik yang kedua destruktif karena lebih banyak menimbulkan efek negatif untuk komunitas.

Upaya-upaya melalui manajemen konflik berbasis komunitas telah dilakukan untuk menyelesaikan konflik yang kedua ini, namun belum ada solusi yang dapat mengatasi konflik ini. Berbeda dengan konflik sebelumnya yang telah ada solusinya, strategi manajemen konflik untuk konflik kedua ini perlu adanya fasilitasi atau mediasi dari pihak-pihak yang memiliki kewenangan atas wisata desa untuk memfasilitasi atau memediasi pihak-pihak yang berkonflik seperti dari Pemerintahan Kecamatan Pamijahan, Dinas Pariwisata Kabupaten Bogor, Dinas Pemberdayaan Masyarakat Desa Kabupaten Bogor dan atau dari PT Indonesia Power. 


\section{DAFTAR PUSTAKA}

Afala, L. M. (2017). Menalar Dinamika Konflik Wisata Goa Pindul. Journal of Governance, 2(1), 18-35. https://doi.org/10.31506/jog.v2i1.2121

Ahsani, R. D. P., Suyaningsih, O., Ma'rifah, N., \& Aerani, E. (2018). Penerapan Konsep Community Based Tourism (CBT) di Desa Wisata Candirejo Borobudur Mewujudkan Kemandirian Desa. Publisia: Jurnal Ilmu Administrasi Publik, 3(2), 135-146. https://doi.org/10.26905/pjiap.v3i2.2270

Asmaniati, F., Hutagalung, H., \& Rosalina Dewi, T. (2017). The Role of Higher Education in Tourism Village Capacity Development. 1st International Conference on Tourism Gastronomy and Tourist Destination, 245-249. https://doi.org/10.2991/ictgtd16.2017 .48

Coser, L. A. (1964). The Functions of Social Conflict. The Free Press.

Creswell, J. W. (2002). Desain Penelitian Pendekatan Kualitatif dan Kuantitatif. KIK Press.

Engel, A., \& Korf, B. (2005). Negotiation and Mediation Techniques for Natural Resource Management. Food and Agriculture Organization of The United Nations. http://search.ebscohost.com/login.aspx?direct=true \&db=lah\&AN=20063021681\&site=e host-live

Falak, S., Chiun, L. M., \& Wee, A. Y. (2014). A Repositioning Strategy for Rural Tourism in Malaysia - Community's Perspective. Procedia - Social and Behavioral Sciences, 144, 412-415. https://doi.org/10.1016/j.sbspro.2014.07.310

Fisher, S., Abdi, D. I., Smith, R., Ludin, J., Williams, S., \& Williams, S. (2001). Mengelola Konflik: Ketrampilan \& Strategi untuk Bertindak (S. . Kartika (ed.); Edisi pert, Vol. 15, Issue 1). The British Council.

Fitriyana, D. (2016). Konflik Manajemen antara Pengelola dan Masyarakat di Tahura Djuanda, Bandung, Jawa Barat. Jurnal Master Pariwisata (JUMPA), 2, 111-123. https://doi.org/10.24843/jumpa.2016.v02.i02.p07

Garsetiasih, R., \& Alikodra, H. S. (2015). Conflict Management of Bulls Conservation in Meru Betiri National Park and Alas Purwo National Park. Jurnal Analisis Kebijakan Kehutanan, 12(3), 213-234.

Hanifah, E. (2018). Analisis Keberlanjutan dalam Penerapan Community Based Tourism Wisata Alam Goa Pindul, Kabupaten Gunungkidul, Yogyakarta. Institut Pertanian Bogor.

Ife, Ji., \& Tesoriero, F. (2016). Community Development - Alternatif Pengembangan Masyarakat di Era Globalisasi. Pustaka Pelajar.

Kinseng, R. A., Nasdian, F. T., Fatchiya, A., Mahmud, A., \& Stanford, R. J. (2018). Marinetourism development on a small island in Indonesia: blessing or curse? Asia Pacific Journal of Tourism Research, 1665(1094), 1-11. https://doi.org/10.1080/10941665.2018.1515781

Kinseng, R. A., Wiryawan, B., Adrianto, L., Monintja, D., Amin, I., \& Zulbairnarni, N. (2013). Indonesia National Coordinating Committe Coral Triangle Initiatives in Coral reefs, Fisheries, and Food Security (Coral Gove). IPB Press. 
Mitchell, R. K., Agle, B. R., \& Wood, D. J. (1997). Toward a Theory of Stakeholder Identification and Salience: Defining The Principle of Who and What Really Counts. The American Psychologist, 28(10), 913-925. https://doi.org/10.1037/h0035597

Mulyana, D. (2004). Metodologi Penelitian Kualitatif. Paradigma Baru Ilmu Komunikasi dan Ilmu Sosial Lainnya. PT Remaja Rosdakarya.

Nizar, M. A. (2015). Tourism Effect on Economic Growth in Indonesia. Munich Personal RePEc Archive (MPRA), 7(65628), 1-25. http://mpra.ub.uni-muenchen.de/65628/

Pariwisata, K. (2018). Rencana Strategis 2018-2019. Kementerian Pariwisata.

Purbasari, N., \& Manaf, A. (2017). Karakteristik Elemen Sistem Pariwisata Ekowisata Desa Wisata Nglanggeran dan Wisata Desa pada Desa Wisata Pentingsari. Jurnal Pembangunan Wilayah \& Kota, 13(1), 100-113. https://doi.org/10.14710/pwk.v13i1.15151

Purmada, D., Wilopo, W., \& Hakim, L. (2016). Pengelolaan Desa Wisata dalam Perspektif Community Based Tourism (Studi Kasus pada Desa Wisata Gubugklakah, Kecamatan Poncokusumo, Kabupaten Malang). Jurnal Administrasi Bisnis S1 Universitas Brawijaya, 32(2), 15-22.

Rahayu, S., Dewi, U., \& Fitriana, K. N. (2016). Pengembangan Community Based Tourism Sebagai Strategi Pemberdayaan Ekonomi Masyarakat di Kabupaten Kulon Progo, Daerah Istimewa Yogyakarta. Jurnal Penelitian Humaniora, 21(1), 1-13.

Rahman, Y., Asbi, A. M., \& Putri, H. T. (2020). Analisis Perubahan Perilaku Ekonomi Masyarakat Sebagai Dampak Pengembangan Pariwisata Berbasis Masyarakat (Studi kasus penggerak wisata desa wisata pesisir Pagar Jaya Kabupaten Pesawaran). Jurnal Nasional Pariwisata, 12(1), 38-50. https://doi.org/10.22146/jnp.52569

Rizkianto, N., \& Topowijono. (2018). Penerapan Konsep Community Based Tourism dalam Pengelolaan Daya Tarik Wisata Berkelanjutan (Studi Pada Desa Wisata Bangun, Kecamatan Munjungan, Kabupaten Trenggalek). Jurnal Administrasi Bisnis (JAB), $58(2), 20-26$.

Sari, I. P., Raden, J., Pagar, F., Bengkulu, D., Regency, W., \& Park, N. (2017). Konflik Kepentingan dalam Pengembangan Pariwisata: kasus Pulau Kapota, Wakatobi, Sulawesi Tenggara. Tsaqofah \& Tarikh, 2(1), 29-38.

Situmorang, R., Trilaksono, T., \& Japutra, A. (2019). Friend or Foe? The complex relationship between indigenous people and policymakers regarding rural tourism in Indonesia. Journal of Hospitality and Tourism Management, 39(March 2018), 20-29. https://doi.org/10.1016/j.jhtm.2019.02.001

Suryadi, Dharmawan, A. H., \& Barus, B. (2020). Ekspansi dan Konflik pada Perkebunan Kelapa Sawit: Kasus di Desa Terantang Manuk, Kabupaten Pelalawan, Riau A Case in Terantang Manuk Village, Pelalawan District, Riau. Sodality: Jurnal Sosiologi Pedesaan, 08(03), 167-178.

Susyanti, D. W., \& Latianingsih, N. (2014). Potensi Desa melalui Pariwisata Pedesaan. Epigram, 11(1), 65-70.

Sutiarani, H., \& Rahmafitria, F. (2016). Dampak Keberadaan Dusun Bambu Terhadap Kondisi Sosial Ekonomi Masyarakat di Desa Kertawangi Kecamatan Cisarua. Tourism Scientific Journal, 1(1), 1-17. https://doi.org/10.32659/tsj.v1i1.1 
Vitasurya, V. R. (2016). Local Wisdom for Sustainable Development of Rural Tourism, Case on Kalibiru and Lopati Village, Province of Daerah Istimewa Yogyakarta. Procedia Social and Behavioral Sciences, 216, 97-108. https://doi.org/10.1016/j.sbspro.2015.12.014

Yachya, A. N., Wilopo, \& Mawardi, M. K. (2016). Pengelolaan Kawasan Wisata sebagai Upaya Peningkatan Ekonomi Masyarakat berbasis CBT (Community Based Tourism) (Studi pada Kawasan Wisata Pantai Clungup Kabupaten Malang). Jurnal Administrasi Bisnis (JAB), 39(2), 107-116. 